\title{
Learning-based intervention for river restoration: analyzing the lack of outcomes in the Ljusnan River basin, Sweden
}

\author{
Peter M. Rudberg ${ }^{1,2,3}$ and Mattijs Smits ${ }^{1}$
}

\begin{abstract}
We focus on a large and sustained stakeholder process for river restoration related to hydropower production that failed to reach any significant natural resource management outcomes. We explore to what extent the stakeholder process can be characterized as a learning-based intervention as well as the reasons for the lack of outcomes. The analysis draws on insights from existing literature of procedural and institutional factors identified to foster and hinder social learning in stakeholder processes. The analysis finds that the stakeholder process featured virtually all fostering procedural factors as well as various fostering institutional factors identified in the literature. The main hindering institutional element consisted of strong pre-existing water rights, granted by the legislation governing hydropower production and river restoration in Sweden. Existing legislation provided a key stakeholder with the power to successfully reach its objective through the unilateral action of exiting the stakeholder process. Our results demonstrate that various learning outcomes, including knowledge acquisition, trust building, and the creation of networks are possible in stakeholder processes that feature power imbalances. The results also suggest that, ultimately, the power imbalance limited the process from reaching significant natural resource management outcomes, both in the short and longer terms. Based on comparison with international cases, the results reveal the need to focus attention on the national scale to remediate power imbalances in stakeholder processes that arise from a share of stakeholders possessing strong prior rights to the use of natural resources. In such cases, sustainable management of natural resources could be better served by efforts to modify existing legislation, rather than investments in resource-intensive learning-based interventions.
\end{abstract}

Key Words: hydropower; learning-based intervention; outcomes; river restoration; Sweden

\section{INTRODUCTION}

Social learning in stakeholder processes related to natural resource management has emerged as an influential strand of academic research during the last decades (Berkes et al. 2002, Keen et al. 2005, Wals 2007, Gerlak et al. 2018). Social learning can be defined as a process of iterative reflection that occurs from sharing experiences, ideas, and environments with others (Keen et al. 2005). A recent review identified that a majority of analyzed social learning processes in the literature refer to learning-based interventions, which can be defined as a government-led (or participatory action research) process to trigger or support social learning (Rodela 2013, Suškevičs et al. 2018). The literature contains numerous assertions related to the beneficial outcomes of social learning in stakeholder processes, including improved decision-making and problem-solving capacity as well as changes in perceptions, values, and norms (Walters 1986, Dale 1989, Lee 1993, Pinkerton 1994, Daniels and Walker 1996, Buck et al. 2001, Röling 2002, Olsson et al. 2004, Folke et al. 2005, Armitage et al. 2008). Ultimately, there seems to be an expectation that successfully facilitated learning-based interventions lead to desirable collective action and natural resource management outcomes (Schusler et al. 2003, Blackmore 2007, Pahl-Wostl et al. 2007, Muro and Jeffrey 2008, Cundill and Rodela 2012).

However, the relationship between learning-based interventions and natural resource management outcomes represents an area in which further research is warranted. Recent literature on learning and natural resource management increasingly focuses on whether and how natural resource management outcomes are, or can be, connected to learning processes (Siebenhüner et al. 2016, Armitage et al. 2017, de Kraker 2017, Suškevičs et al. 2018). However, Suškevičs et al. (2018) explicitly highlighted a shortage of analysis of 'failed' learning processes in the literature, i.e., processes that did not result in the expected outcomes.

We focus on a case that, as we argue, can be analyzed as a failed learning-based intervention in the Ljusnan River basin (referred to hereafter as the Ljusnan process). The Ljusnan process ran between 2000 and 2007 and focused on river restoration of Sweden's eighth most important basin in terms of hydropower production (Swedish Energy Agency 2014). The vision of public stakeholders, who initiated the process, was to recreate an ecologically sustainable river basin with varied natural and cultural environments in line with national and European Union (EU) environmental policy. Moreover, the Ljusnan process was initiated with the intention of constituting a model for coordinated hydropower permit reviews for river restoration in Sweden, the largest hydropower producer in the EU (CAB 2008, EC 2018). However, in 2007, after 25 project meetings, with an average of 12 participants per meeting and producing 21 project reports, the main hydropower producer in the basin exited the Ljusnan process, effectively ending it without any river restoration measures.

We aim to explore the relationship between learning-based interventions and natural resource management outcomes. We do so by outlining a research framework based on key factors identified in the literature to foster or hinder social learning and by applying it to the Ljusnan process. In doing so, we are guided by the following questions: (1) to what extent can the Ljusnan process be characterized as a learning-based intervention and (2) how do procedural and institutional factors related to the Ljusnan process explain its lack of natural resource management outcomes? 
Table 1. Research framework identifying procedural and institutional fostering and hindering factors of social learning that will be applied to the Ljusnan process.

\begin{tabular}{lll}
\hline \hline & Fostering & Hindering \\
\hline Procedural factors & • Sustained interaction (1) & \\
& - Joint knowledge acquisition, sharing, and & \\
& deliberation (2) & \\
& - Skilled facilitation (3) & \\
& - Inclusion of relevant stakeholders (4) & • Authorities lacking experience, facing spatial \\
Institutional factors & Social capital and networks (5) & misfits, and problems of coordination (8) \\
& - Capability of formalizing new practices, & - Stakeholders possessing strong pre-existing rights \\
& arrangements, norms, and values (6) & \\
& - An organization that fits the relevant ecological natural resource (9) \\
& unit (7) & \\
\hline
\end{tabular}

By answering these questions, we contribute to the knowledge of learning-based interventions that are initiated with the aim of reaching tangible natural resource management outcomes, including environmental policy implementation (Blackmore et al. 2007, Ison et al. 2007, Steyaert and Jiggins 2007, Pahl-Wostl et al. 2008). Such knowledge is increasingly valuable given the current trend toward promoting stakeholder participation, voluntary agreements, and learning to implement environmental policy in the EU (Knill and Lenschow 2000, Jordan et al. 2005, Newig and Koontz 2014). Furthermore, there are few analyzed cases in the literature of extensive and sustained stakeholder processes that have failed to reach any significant natural resource management outcomes. As such, insights from the Ljusnan process can contribute to knowledge of how, when, as well as when not to, initiate learning-based interventions aimed at implementing environmental policy.

\section{PROCEDURAL AND INSTITUTIONAL FACTORS FOSTERING OR HINDERING SOCIAL LEARNING}

Social learning is the dominant learning conceptualization in the environmental policy and natural resource governance literature (Gerlak et al. 2018, Suškevičs et al. 2018). Most learning-based interventions in the literature are analyzed using social learning as the key learning concept (Suškevičs et al. 2018). Therefore, we focus on insights from the body of literature related to social learning to build our research framework to analyze the Ljusnan process (Table 1). The framework is based on insights from three extensive reviews of social learning in natural resource management and governance literature: Muro and Jeffrey (2008), Cundill and Rodela (2012), and Siebenhüner et al. (2016). These three review articles represent authoritative reviews on the state of the social learning literature, as indicated by their extensive citations in subsequent literature (Muro and Jeffrey 2008) and in the robust method used to reach their findings (Cundill and Rodela 2012, Siebenhüner et al. 2016).

Muro and Jeffrey (2008), in a review of the theory and application of social learning, identified a range of procedural factors directly related to the structure and functioning of the stakeholder process, which supports social learning. For Muro and Jeffrey (2008), these included facilitation, repeated meetings, open communication, unrestrained thinking, and diverse stakeholder participation. Cundill and Rodela (2012) found that consensus emerged about similar procedural elements that support social learning, including sustained interaction between stakeholders, ongoing deliberation, and sharing of knowledge in a trusting environment. The two reviews thereby identify similar fostering procedural factors, which in our framework are expressed as: (1) sustained interaction; (2) joint knowledge acquisition, sharing, and deliberation; (3) skilled facilitation; and (4) inclusion of relevant stakeholders. No specific hindering procedural factors are identified in the reviews.

Sibenhüner et al. (2016) found that the most recurring fostering factors identified for the emergence of social learning processes in their sample are informal and formal institutions. Informal institutions are exemplified as social capital and networks in the shape of relationships and trust whereas formal institutions refer to administrative and legislative elements embedding the process. In the papers reviewed by Sibenhüner et al. (2016), it is possible to find examples of fostering institutional factors, e.g., capability of formalizing new practices, arrangements, norms, and values (from Steyaert and Jiggins 2007) and the existence of an organization that fits the relevant ecological unit, such as a basinwide organization in the case of water management (from Mostert et al. 2007). Reversely, scalar misfits between administrative and ecological units was identified as a hindering institutional factor in the literature included in Sibenhüner et al.'s sample (from Borowski et al. 2008). Muro and Jeffrey (2008) identified a very rigid institutional framework as a condition that limits opportunities for social learning processes. In reviewed papers by Muro and Jeffrey (2008), it is possible to find examples of hindering institutional factors in the shape of authorities that lack experience with multiparty stakeholder approaches or that experience scale and intrarelational difficulties, as well as stakeholders possessing strong pre-existing rights over the natural resource in question (from Mostert et al. 2007). The two reviews thereby identify institutional factors, defined as broader values, administrative and legislative elements embedding the stakeholder process, as fostering the emergence of, or limiting the opportunities for, social learning. In the framework, we express fostering institutional factors identified in the reviews as: (5) social capital and networks; (6) capability of formalizing new practices, arrangements, norms, and values; and (7) an organization that fits the relevant ecological unit. Institutional factors hindering social learning are expressed as: (8) authorities lacking experience, 
facing spatial misfits, and problems of coordination; and (9) stakeholders possessing strong pre-existing rights over the natural resource.

Table 1 shows the research framework, grouping identified factors into fostering and hindering procedural and institutional factors. This presentation allows for the creation of a simple and parsimonious framework, with only two overall categories that cover the most significant factors identified in the three reviews. This framework does not intend to be an exhaustive list of factors fostering or hindering social learning in stakeholder processes, but instead to provide a concise framework to analyze learningbased interventions based on authoritative reviews of critical factors. Appendix 1 exhibits all the identified factors in each of the three review publications and illustrates how we arrived at the final grouping and expression of factors.

Having outlined this framework, we emphasize that we are conscious of the fact that stakeholder processes featuring social learning are not guaranteed, nor can they always be expected to lead to natural resource outcomes (Reed et al. 2010). Our focus is however on learning-based interventions applied purposefully by stakeholders (e.g., researchers or governmental bodies) to implement environmental policy and yield natural research management outcomes. Although learning-based interventions that lead to, for example, changed mental models of a natural resource situation can be highly valuable to analyze social learning as a social process, they are of less value to implement environmental policy if they cannot be related to any natural resource management outcomes.

\section{THE LJUSNAN RIVER BASIN AND PROCESS}

Sweden is the biggest hydropower producing EU member state and the Ljusnan River basin is, in turn, Sweden's eighth most significant hydropower producing basin (Swedish Energy Agency 2014). There are just over 40 hydropower stations in the basin, as well as an additional 50 hydropower dams, with a total production capacity of $829 \mathrm{MW}$ and an average yearly production of $3.9 \mathrm{TWh}$ (CAB 2003, Swedish Energy Agency 2014). One hydropower company is dominant in the Ljusnan River basin with $95 \%$ of the total production capacity (Fortum 2017).

Hydropower dams and stations in the Ljusnan River basin are predominantly regulated with permits granted according to the Swedish Water Law of 1918, which was in force until 1984 (CAB 2003). These hydropower permits were granted with no time limit and specify the operating conditions of the stations and dams, including maximum and minimum head of dams as well as water flow into turbines. Requirements of environmental protection, such as passage facilities and minimum flow, are minimal because the permits were primarily crafted to maximize energy production (CAB 2003). To modify a hydropower permit to allow for river restoration, proposed reviews must be brought to the Swedish Land and Environmental Court and processed, as well as decided, separately by the court for each individual hydropower station or dam (Rudberg et al. 2015). These permit reviews are generally initiated by public authorities and Swedish legislation specifies requirements and limitations regarding the permitted extent and scope of environmental measures as part of a permit review. One significant limit is what could be called the "compensation free" limit for river restoration measures. This limit establishes that proposed environmental measures are not allowed to cause a reduction of more than $5 \%$ of the production value of a hydropower station or dam holding a permit according to the Swedish Water Law from 1918 (SFS 1998, 39 §). If more environmental measures are implemented as part of a permit review at such a station or dam, the public authority pursuing the permit review must provide monetary compensation to the hydropower producer for losses exceeding the limit of 5\% of its production value.

The Ljusnan process included representatives from two county administrative boards, five municipalities, and five hydropower companies in the basin. The process was initiated by Gävleborg and Jämtland Country Administrative Boards (CAB) and the five municipalities Söderhamn, Ljusdal, Bollnäs, Ovanåker, and Härjedalen, all situated in the Ljusnan River basin (CAB 2003). The process was divided into two phases: phase one with only public stakeholders (CAB and municipality representatives) that ran between the years 2000 and 2003, and phase two that included industry stakeholders and ran between 2003 and 2007.

The vision and goals of the Ljusnan process were formulated by the public actors in phase one of the Ljusnan process based on national and EU environmental policy (CAB 2003). The vision was to recreate an ecologically sustainable river basin with varied natural and cultural environments. The project goals were formulated as follows: continue hydropower production with regards to 21 st century values; increase biodiversity; recreate aquatic habitats in dry reaches of the river; ensure fish passage at artificial barriers; improve natural reproduction; increase the social and touristic values of the basin; and work in cooperation with concerned actors. The type of river restoration measures contemplated to achieve these goals were the creation of passage facilities, establishment of mandatory minimum flows, as well as the removal of small hydropower stations in the basin.

The core idea behind the Ljusnan process was to transcend the legislated compensation free limit for environmental measures of each station or dam by transforming it into an overall river basin scale compensation free limit. Such a basin-wide limit would be calculated by adding the individual limit of $5 \%$ for each station and dam in the Ljusnan River basin. The overall basin scale limit could then be used more focused and effectively because some stations, with potentially high environmental benefits from restoration measures, could benefit from measures that would result in production losses exceeding $5 \%$ of its production value. The overall basin-wide limit of production loss from measures would not be surpassed because other stations and dams, with less environmental potential from measures, would be left unmodified in the basin. The production loss from environmental measures, at a basin scale, would thereby be kept below $5 \%$ of the total hydropower production value of the basin.

An overall basin-wide limit would be relatively simple to operationalize in the Ljusnan River basin because of the presence of one single dominant hydropower producer. Cooperation between public representatives and operators would serve to jointly identify and agree on objectives and measures with the highest potential for environmental benefits within the overall river basin compensation free limit of environmental measures. The most appropriate shape, focus, and distribution of compensation free environmental measures in the river basin was 
thereby an open-ended question that was to be answered through joint investigation and deliberation between public and private representatives.

\section{METHODOLOGY}

We focus on a single case, the Ljusnan process, as a revelatory case study of a learning-based intervention aimed at implementing environmental policy. The relevance of the case is underlined by the strong political interest in the process from the Swedish Association of Municipalities because the Ljusnan process was intended to constitute a model for coordinated hydropower permit reviews for river restoration in Sweden (CAB 2008).

The empirical material consisted of the meeting minutes from 25 stakeholder meetings of the Ljusnan process, semistructured interviews with 5 key participants in the Ljusnan process, and 21 project reports, including reports on existing hydropower permits in the basin, biotope and fish mappings, and trial water release accounts. The empirical material was analyzed and presented using framework synthesis (Barnett-Page and Thomas 2009) through a search of evidence of procedural and institutional fostering and hindering factors of social learning in the Ljusnan process, as identified in the research framework (Table 1). The triangulation of meeting notes, interview replies from key participants, and project reports ensures a high level of internal validity of the insights and conclusions.

Project documentation formally identified 22 representatives as part of the Ljusnan process. Five key participants were selected for an interview by asking the coordinator of the process, i.e., the first interviewee, who the most active and relevant participants to interview were (snowball sampling). Based on this initial list, interviewees were chosen to ensure that representatives from the dominant hydropower producer (industry representatives A and $\mathrm{B})$, the two CABs (the coordinator, who represented CAB A, and a representative from $\mathrm{CAB} B$ ) as well as a municipal representative from the biggest and most active municipality in the basin were included.

Open interview questions were developed in which the interviewees were asked for their experiences of the process, identification of project outcomes, and their explanations of these outcomes. The questions were sent out prior to the interview and summary notes were taken during the interviews. The interviews lasted for about one hour and were conducted by phone between December 2016 and February 2017. They were not recorded to ensure as earnest answers and open communication as possible. The two industry interviewees were sent the summary notes and provided their approval of the documented replies.

Carrying out interviews 10 years after the finalization of the Ljusnan process represents a potential source of error because interviewees may have forgotten important aspects of the process. Various measures were taken to limit this risk. Interview questions were sent out prior to the interviews to give the respondents time to think and remember relevant aspects of the process. Replies were also extensively validated by referring to the detailed meeting minutes from 25 stakeholder meetings. Some advantages of the delayed interviews include that sufficient time has elapsed for possible time-lagged outcomes from the process to materialize. Furthermore, because most interviewees were retired and had no formal obligations toward their former employers, it provided conditions for more open and earnest answers.

\section{ANALYZING THE LJUSNAN PROCESS}

We use the research framework from Table 1 to analyze procedural and institutional elements related to the Ljusnan process. The numbers in the headings refer to the factors in the table.

\section{Fostering procedural elements}

\section{Sustained interaction (1)}

In the Ljusnan process there is ample evidence of sustained interaction between all stakeholders from the end of 2003 to the end of 2007, four years in total. There are meeting notes from 18 project meetings featuring representatives from CABs, municipalities, and industry stakeholders. Three meetings were two-day meetings that included excursions, dinners, and ample time for interaction between the stakeholders.

Joint knowledge acquisition, sharing, and deliberation (2)

The Ljusnan process can be characterized as containing both separated and joint knowledge acquisition, sharing, and deliberation. A large portion of the knowledge acquisition of the project took place during the first phase of the project in which only public actors, i.e., $\mathrm{CAB}$ and municipality representatives, participated. Four project summary reports, two biotope mapping reports, and one trial water release account were developed and published prior to the formal inclusion of industry representatives in the Ljusnan process. A significant portion of the knowledge acquisition of the project was thereby not carried out jointly with industry representatives.

During the second phase of the project, in which industry representatives participated, there are several important examples of joint knowledge acquisition as well. There are reports of 4 jointly conducted trial water releases, and there was an active working group during the second phase that met 10 times, which can be identified as a forum for joint knowledge acquisition. Interviewees described the working group as a forum where problems were raised, examined, and discussed. As industry representative B recalls: "The work largely consisted in knowledge acquisition and sharing between different interest groups and participants." Industry interviewee A also explained how he informed the public stakeholders of problems of nutrient limitation and salmon disease that led to trials of release of salmon fry as an alternative option for salmon reintroduction in Ljusnan. Meeting notes from meetings 13, 16, and 19 support industry representative A's account and thus provides evidence of joint knowledge acquisition, sharing, and deliberation in the Ljusnan process related to salmon reintroduction.

\section{Skilled facilitation (3)}

The Ljusnan process appears to have been skillfully facilitated until the end of 2006 when the coordinator of the process, $\mathrm{CAB}$ representative $A$, retired. Industry representative A praised the work of the coordinator of the project who managed the project until 2006: "The coordinator managed the project in an excellent way. You could trust his word and he made sure there was speed and direction in the work." CAB representative B expressed equally positive sentiments toward the coordinator's facilitation skills. The retirement of the coordinator therefore did, in the view of industry representative $\mathrm{A}$, as well as the coordinator himself, 
influence the process negatively. However, CAB representative B and the municipality representatives, even when asked specifically, did not experience the retirement of the coordinator as a decisive shift in the Ljusnan process nor decisive for the outcome of the project, as recalled by the municipal representative: "My recollection is that the retirement of the coordinator did not influence the project noticeably."

\section{Inclusion of relevant stakeholders (4)}

The inclusion of representatives from the two county administrative boards, five municipalities, and five hydropower organizations in the Ljusnan River basin ensured the inclusion of relevant stakeholders in the Ljusnan process. However, the Legal, Financial and Administrative Services Agency (LFASA), the main national agency in Sweden initiating permit reviews for river restoration related to hydropower production, was a key stakeholder that was missing from the Ljusnan process. Representatives from LFASA were invited to participate but chose not to, because, as recalled by $\mathrm{CAB}$ interviewee $\mathrm{B}$, they did not think that the Ljusnan process was feasible given the existing legislation governing hydropower production and river restoration: "They [LFASA] said that [the Ljusnan process] was a completely impracticable way forward."

There are various NGOs in Sweden that have an interest in river restoration, including in the Ljusnan River basin, that did not participate directly in the process. As the municipal representative explained on the nonparticipation of NGOs: "[NGOs did not participate] but I continuously informed the local fishing associations and the Swedish Society for Nature Conservation." There are, however, no indications that the lack of inclusion of NGO stakeholders had any significant negative influences on the Ljusnan process.

\section{Fostering and hindering institutional elements}

\section{Social capital and networks (5)}

The interview responses indicate that the Ljusnan process was permeated by mostly positive relationships and trust among stakeholders. All interviewees stated that there was a respectful environment in the project and that the collaboration went well. Industry representative A mentioned that he felt trust toward the coordinator of the project and $\mathrm{CAB}$ representative $\mathrm{B}$ said that he was trusting toward the industry representatives. The municipal representative stated that there was a positive spirit in the process because it felt like they were all working toward the same goal. Or, in the words of industry representative B: "[The cooperation] worked very well. We became very close, there was understanding and respect."

The Ljusnan process also appears to have contributed to the creation of positive relationships and networks among the participants as recalled by the coordinator: "Municipality, CAB, and industry representatives met and rubbed off on each other... indirectly it created networks...we got to know each other and each side's arguments." Industry representative B's opinion coincides with this evaluation of the process: "The positive part is that we gained a larger network, an increased understanding of the values of the basin as well as what the public authorities prioritize. The knowledge exchange of the project was beneficial."
Capability of formalizing new practices, arrangements, norms, and values (6)

The first phase of the Ljusnan process, which included representatives from the two $\mathrm{CAB}$ and five municipalities in the Ljusnan River basin, shows evidence of institutional capability to formalize new practices and arrangements. The Ljusnan process was an attempt to develop a model for combined permit reviews in river basins affected by hydropower production and as such departed from previous practices of river restoration in Sweden (CAB 2008). In interviews, the coordinator explained how the participants from each $\mathrm{CAB}$ and municipality in the Ljusnan process managed to cooperate, reach agreement, and embed the decisions taken in the Ljusnan process formally among politicians and civil servants of each municipality and CAB in the Ljusnan River basin: "The working group compiled [the work] and the civil servants in each municipality embedded it in their respective organization. I embedded the work at the $\mathrm{CAB}$ as well as politically." Although it is more difficult to say something about formalizing new norms and values, our findings do not reveal any evidence that points toward a lack of such a capability among the authorities that participated in the Ljusnan process.

An organization that fits the relevant ecological unit (7)

No basin-wide institution existed nor was created to cover the whole Ljusnan River basin. However, the public authorities present in the Ljusnan process, both at the county and municipal levels, covered the Ljusnan River basin almost entirely. The first phase of the Ljusnan process was, in addition, dedicated to the cooperation and agreement among the participating public authorities. This allowed them to act in a coordinated and similar way to one basin-wide institution in phase two of the Ljusnan process. This was confirmed by the coordinator who mentioned that there were no problems of cooperation between public actors: "It worked well. We were all on the same side which made it simpler despite some differences in the angle of incidence."

Authorities lacking experience, facing spatial misfits, and problems of coordination (8)

In phase one of the Ljusnan process, public authorities at county and municipal levels in the Ljusnan River basin had the opportunity to coordinate the positions and mode of cooperation. Although there is evidence from the interviews that there was a difference in opinion and style between the public representatives in the Ljusnan process, there is no evidence that participants faced difficulties in terms of coordination and lack of experience from stakeholder processes. The CAB and municipalities present in the Ljusnan process also effectively covered the whole of the Ljusnan River basin, which meant that there was a good fit between the administrative and biophysical units.

\section{Stakeholders possessing strong pre-existing rights over the} natural resource (9)

The hydropower producers that participated in the Ljusnan process were in possession of strong water rights for hydropower production. Permits for hydropower production are unlimited in time in Sweden and very difficult to modify against the wishes of the operator. Apart from staying within the legislated compensation free limit for river restoration measures, the public agency proposing a permit review must provide technical studies 
and documentation to persuade the court that the proposed changes, such as mandatory minimum flow releases and construction of passage facilities, are technically feasible, reasonable, and do not lead to the imposition of conditions that significantly interfere with hydropower production (Rudberg et al. 2015).

Interviewees agreed that most public representatives in the Ljusnan process underestimated the important hurdles facing public authorities pursuing a hydropower permit review. Interviewed participants further concurred that one of the main reasons for the lack of outcomes from the Ljusnan process was that the dominant hydropower producer in the basin did not agree with the public stakeholders' basic idea that there existed a compensation free limit for river restoration measures. The legislated compensation free limit for river restoration measures is rather only one of several limitations established by Swedish legislation restricting the opportunities and scope for river restoration measures. Other notable limitations include that the public authorities initiating a review bear the burden of proof and must convince the court that proposed river restoration measures are reasonable considering its costs and benefits. In the words of industry representative A: "From [the public side] there was a general and unrealistic faith in the opportunities for permit reviews ... the legislation also contains a clause requiring that the costs of measures should match the benefits."

Industry interviewee B explained that the objective of the main hydropower producer in the basin was to limit the production loss of the envisioned environmental measures. They therefore attempted to focus the work of the Ljusnan process on tributaries, with smaller hydropower stations than the main river, in which river restauration measures would lead to minimal production losses. Project reports from phase two also revealed that industry representatives introduced the idea of hydropower expansion by constructing new installations in the Ljusnan River basin to compensate for the production loss of envisioned river restoration measures. This suggestion did not prosper and in 2007, toward the end of the Ljusnan process, the public side made an offer of proposed measures that included the creation of 16 passage facilities, the increased minimum flow at 19 , and the removal of an additional 4 hydropower stations and dams in the Ljusnan River basin (CAB 2007). The public side calculated that this offer would create a cumulative production loss, because of environmental measures, of just over $2 \%$ of the basin's total hydropower production value.

The response of the main hydropower producer to the public side's formal offer was to exit the Ljusnan process because, in the words of industry representative B: "According to their [the public actors'] opinion the public could demand 5\% of [production] value without compensating. They placed their offer at half that sum and believed it to be a good compromise. We were, at the time, unable to continue working on those terms and it all stopped." In the formal reply, the dominant hydropower producer in the basin justified the decision to exit the Ljusnan process by reference to global warming as the dominant environmental threat and arguing that hydropower production should not be reduced because of its key role in mitigating climate change.

\section{DISCUSSION}

\section{Can the Ljusnan process be characterized as a learning-based intervention?}

Judging from the in-depth analysis of the process goals, documents, and interviews with key stakeholders, the Ljusnan process fits our definition of social learning as a process of iterative reflection that occurs from sharing experiences, ideas, and environments with others. It can also be considered a learning-based intervention because government-led participation was meant to trigger or support social learning. In addition, the empirical material demonstrates the presence of various significant procedural factors identified to support social learning, such as sustained interaction and joint knowledge acquisition, sharing, and deliberation.

There are however different strands of thinking and numerous definitions of social learning in the literature (Dyball et al. 2007, de Kraker 2017). Indeed, some more stringent definitions of social learning include requirements to demonstrate changes in understanding that go beyond the individual and occur through interaction in a social network (Reed et al. 2010), the creation of a common vision and priorities (Dyball et al. 2007), or at least evidence of convergence of ideas among stakeholders regarding both goals and means to deal with a problem (Van Bommel et al. 2009). The application of one of these more stringent definitions of social learning would question whether the Ljusnan process was a social learning process at all. The vision and goals of the Ljusnan process were, for example, formulated among public stakeholders and the hydropower operators intended, and failed, to include hydropower expansion as a goal in the process to compensate for envisioned production losses from environmental measures.

Although the preceding paragraph illustrates that there is scope for valid disagreement, we still argue that overall there are sufficient arguments to characterize, and meaningfully analyze, the Ljusnan process in terms of a learning-based intervention.

\section{Outcomes from the Ljusnan process}

Suškevičs et al. (2018) proposed a list of five types of possible learning outcomes from learning processes related to natural resource management. Analyzed as a learning-based intervention, the empirical material presented from the Ljusnan process shows evidence of changes that fits into various of these defined learning outcomes, including knowledge acquisition, changes in individuals' feelings toward each other, and changes in networks. A different methodology, including participant observation and prior and postprocess interviews, would have shed additional insight into some of the cognitive and relational processes at work during the Ljusnan process.

Our primary focus is, however, on learning-based interventions to implement environmental policy, which require natural resource management outcomes. There were no such outcomes as a direct result of the Ljusnan process. Ten years after the finalization of the process, it is not possible to find much evidence that the knowledge acquisition, trust building, and network creation that did occur in the process, even in a longer term, has resulted in significant natural resource management outcomes in the basin. From the interviews and available documentation, it 
was only possible to relate two natural resource management outcomes in the basin to the Ljusnan process: one permit review in 2015 to increase the minimum flow of one hydropower station and a loach restoration project during 2009-2012 in the upper reaches of the basin. Given the time and resources spent on the Ljusnan process and compared to the public side's proposed restoration measures, even these long-term natural resource management outcomes can be considered insignificant.

\section{Critical role of legislation}

The in-depth analysis of the Ljusnan process shows that it featured a significant number of procedural and institutional elements identified to foster social learning. The Ljusnan process featured sustained interaction, joint knowledge acquisition, sharing, and deliberation in a trusting environment. Until the end of 2006 there is evidence of skilled facilitation of the process and all stakeholders present in the process were relevant. The public authorities leading the Ljusnan process exhibited the capability of formalizing new practices related to river restoration as well as the capacity to coordinate and lead the stakeholder process. The fit between the biophysical scale of the Ljusnan River basin and the administrative scale of the public authorities participating in the Ljusnan process was also appropriate. Despite exhibiting all these fostering procedural and institutional factors, the Ljusnan process has resulted in insignificant natural resource management outcomes, even 10 years after its finalization. The main hindering institutional factor identified in the Ljusnan process, i.e., strong pre-existing water rights among a share of stakeholders, provides a compelling explanation for this result.

Institutions can be analyzed as expressions of power to protect interests of certain groups, and legislation as formally sanctioned rules to regulate conflict in situations in which interests cannot be harmonized (Vatn 2005). A learning-based intervention that includes negotiation of incompatible interests and zero-sum interactions, as was the case with the Ljusnan process, can therefore be expected to be heavily influenced by the legislation embedding the process. The underlying assumption from the public side in the negotiations was that a lack of agreement in the Ljusnan process would result in extensive, case by case, permit reviews of various hydropower stations in the basin that, in the end, would result in higher production losses and costs for the operators (CAB 2007). The strong pre-existing water rights among the hydropower operators, granted by legislation governing hydropower production and river restoration in Sweden, undermined this assumption. Existing legislation granted the hydropower producers the power to successfully reach its objective, i.e., limiting production loss, through the unilateral action of exiting the Ljusnan process.

Power is repeatedly brought up in the literature of participation and social learning (van den Hove 2006, Reed 2008, Crona and Parker 2012). Some authors even identify power or power imbalances as determinant of social learning (Ison et al. 2007, Rodela 2013, de Kraker 2017). The Ljusnan process sheds light on the role of legislation in determining stakeholder interdependence in a learning-based intervention because it ultimately granted one stakeholder the power to successfully take unilateral action. Although our results from the Ljusnan process show that various learning outcomes are possible in stakeholder processes that feature important power imbalances, including knowledge acquisition, trust building, and creation of networks; they also suggest that the power imbalance limited the process from reaching significant natural resource management outcomes. In other words, the conflict originating from zero-sum interactions between river restoration and hydropower production could not be overcome through the learning-based intervention given the existing legislation, despite the process' excellent procedural elements.

It is, however, also possible to interpret some actions of the public stakeholders as displays of power that limited the scope of possible solutions and thereby contributed to the lack of outcomes (Van Bommel et al. 2009). In particular, by defining the vision and goals of the Ljusnan process in line with EU and national environmental policy, public stakeholders reserved the prerogative of problem definition and structuring, and thereby limited the range of politically acceptable arguments and solutions (Hisschemöller and Hoppe 1995). This is illustrated in the Ljusnan process by the failure of hydropower producers to introduce the goal of hydropower expansion as a compensation for possible production losses from environmental measures. The suitability of these actions by public authorities ultimately boils down to a discussion of whether public stakeholders, guided by environmental policy, possess higher legitimacy to define environmental problems compared to other stakeholders, guided by private or corporate considerations.

Comparing the Ljusnan process with learning-based interventions for river restoration related to hydropower production in the $\mathrm{EU}$ and US

To put our findings into perspective and to allow for additional material to explore the role of the legislation embedding a learning-based intervention, we compared the findings from the Ljusnan process with two well-documented cases harboring very different outcomes. The first case is a learning-based intervention in the form of a stakeholder process conducted between 1992 and 2004 in the Dordogne basin in the south of France (Barraqué et al. 2004). This case is similar both in terms of scale of hydropower production, 58 dams and 28 hydropower stations with a production capacity of $1550 \mathrm{MW}$ (EDF 2015), and the two major issues at stake in the process, i.e., (1) the impact of hydropower discharges on water quality and levels, and (2) the management of the aquatic environment (Barraqué et al. 2004, Mostert et al. 2007). The reported outcome from the Dordogne stakeholder process, in terms of river restoration measures related to hydropower production, were limited to an agreement to increase the minimum flow downstream one hydropower dam in the basin. The authors identified the governance structure and the preexisting distribution of water rights as the main obstacles to allow for social learning in the stakeholder process (Barraqué et al. 2004, Mostert et al. 2007). Hydropower concessions in France are granted for 75 years and in the Dordogne basin the first ones would come to an end after 2010.

The second case, in the Penobscot basin in the USA, is a learningbased intervention in the form of a stakeholder process to relicense various hydropower projects according to the US Integrated Licensing Process. This hydropower licensing process, developed in 2003, aims to increase public participation and find ways for stakeholders to reach agreements outside of the courtroom (FERC 2011, Opperman et al. 2011a). This 
stakeholder process concerned hydropower stations and dams, producing on average $0.3 \mathrm{TWh} /$ year, and led to an agreement that included various river restoration measures, including the removal of the two most seaward dams and new, or improved, passage facilities at five dams in the basin (Opperman et al. 2011a). The measures drastically improved access for various migrant species in the river and, through capacity and operational changes of existing stations, maintained the total basin energy generation at previous levels. Opperman et al. (2011b) identified three factors that facilitated the comprehensive approach in the stakeholder process: previous conflicts and expenses that had accompanied the relicensing of individual nonfederal hydropower dams, single ownership of the hydropower facilities, and the legal battle over the status and rights of the Penobscot Indian Nation in hydropower licensing decisions.

Similar to the Ljusnan process, these two cases suggest that the legislation embedding a learning-based intervention conditions the possibility of reaching significant natural resource management outcomes. In the Ljusnan River basin, the legislation, in the form of indefinite permits for hydropower production that are very hard to modify, allowed the main hydropower operator to reach its objective of limiting production losses through unilateral action. The public stakeholders in the Ljusnan River basin, on the other hand, almost completely failed to meet any of their objectives in the basin. Similarly, in the Dordogne basin, there was a very limited river restoration outcome reported from the stakeholder process, which in part can be related to the fact that the hydropower producers in the process were in possession of strong pre-existing water rights for hydropower that, at the time of the study, were still many years from expiring.

By contrast, in the Penobscot basin, it can be argued that two identified legislative features, hydropower licenses that expire regularly and the granting of special rights to Native Americans of natural resources on their tribal lands, are factors that create a level of interdependency of stakeholders that facilitated the reaching of a comprehensive hydropower licensing agreement. The legal arrangements in the USA related to river restoration and hydropower production provided stakeholders in the Penobscot basin with tools to effectively challenge and thwart the possibilities for the hydropower operator to reach its objectives through unilateral action. The combination of river restoration measures with capacity and operational changes of existing stations, to maintain the total basin energy generation, also evidences the possibility, in some cases, of escaping zero-sum interactions through adopting a basin-scale approach. Besides the Penobscot case, there are other examples of river basins in the USA that exhibit similar legislative arrangements, i.e., river basins on Native American tribal land and the relicensing of hydropower projects, in which stakeholders have agreed on collaboratively negotiated proposals that include significant river restoration outcomes (Birge et al. 2014, Chaffin et al. 2016).

\section{CONCLUSION}

We explored the relationship between learning-based interventions and natural resource management outcomes by focusing on the Ljusnan process. This stakeholder process represents an important and sustained effort for river restoration associated with hydropower production, which failed to reach any significant natural management outcomes. We discussed to what extent the Ljusnan process can be characterized as a learningbased intervention, and developed a research framework to analyze how related procedural and institutional factors can explain the lack of natural resource management outcomes.

We concluded that the Ljusnan process can be meaningfully analyzed as a learning-based intervention and that it featured virtually all procedural and institutional factors understood to foster social learning. The main hindering institutional element consisted of hydropower producers possessing strong pre-existing water rights, granted by Swedish legislation governing hydropower production and river restoration. This situation gave the dominant hydropower producer the power to successfully reach its objective, i.e., limiting production loss, through the unilateral action of exiting the Ljusnan process. The Ljusnan process does show that various learning outcomes, such as knowledge acquisition, trust building, and creation of networks, are possible in stakeholder processes that feature significant power imbalances. The same power imbalances were, however, crucial in stopping the learning-based intervention from reaching significant natural resource management outcomes.

The analysis of the Ljusnan process, as well as a comparison with cases in the EU and the USA, therefore highlight the paramount role that the legislation surrounding a learning-based intervention has on the prospect of reaching significant natural resource management outcomes. As such, future research, as well as policy initiatives, could further investigate the possibility of initiating learning interventions in combination with hydropower relicensing in various mature hydropower producing countries. This includes various EU member states and nonfederal hydropower projects in the USA that have systems of granting hydropower production rights that are limited in time and periodically renegotiated. Sweden is excluded from such research efforts until the end of 2018 because hydropower permits, until that time, have no time limit. Important legislative adjustments have however been passed in the Swedish parliament, and will enter into force in January 2019, including a general limit to the term of hydropower permits of 40 years and shifting the burden of proof in permit review trials to hydropower operators. These changes constitute significant modifications to the legal arrangements surrounding river restoration and hydropower production and could provide a unique research, as well as policy, opportunity in Sweden to revisit learning-based interventions for environmental policy implementation in this area.

More generally, our research findings highlight the importance of assessing the legislative setting of a natural resource management situation prior to engaging in a sustained learningbased intervention. In many parts of the world, various stakeholders have prior rights to the use of natural resources and existing legislation can make it virtually impossible to modify such rights against these stakeholders' wishes. In such circumstances, sustainable management of natural resources could be better served by efforts to modify existing legislation to increase stakeholder interdependency, rather than in resource-intensive, learning-based interventions with a high risk of insignificant outcomes. 
Responses to this article can be read online at: http://www.ecologyandsociety.org/issues/responses. $\mathrm{php} / 10472$

\section{Acknowledgments:}

The authors thank Arthur Molfor his insightful comments at various stages of the writing process. This article also benefited greatly from the anonymous reviewers who provided challenging but constructive criticism. Finally, we thank the interviewees who provided their time as well as earnest answers to our questions. This research did not receive any specific grant from funding agencies in the public, commercial, or not-for-profit sectors.

\section{LITERATURE CITED}

Armitage, D., A. Dzyundzyak, J. Baird, Ö. Bodin, R. Plummer, and L. Schultz. 2017. An approach to assess learning conditions, effects and outcomes in environmental governance. Environmental Policy and Governance 21(1):3-14. https://doi.org/10.1002/ eet.1781

Armitage, D., M. Marschke, and R. Plummer. 2008. Adaptive comanagement and the paradox of learning. Global Environmental Change 18(1):86-98. http://dx.doi.org/10.1016/j.gloenvcha.2007.07.002

Barnett-Page, E., and J. Thomas. 2009. Methods for the synthesis of qualitative research: a critical review. BMC Medical Research Methodology 9(1):59. http://dx.doi.org/10.1186/1471-2288-9-59

Barraqué, B., J.-P. Le Bourhis, P. Maurel, and R. Raymond. 2004. Public participation in the Dordogne River basin case study. HarmoniCOP Project. European Commission, Brussels, Belgium. [online] URL: http://www.harmonicop.uni-osnabrueck. de/ files/down/Final $\% 20$ WP $\% 20$ French $\% 20$ Case $\% 20$ Study $\% 20$ Report $\%$ 2029Nov\%2004.pdf

Berkes, F., J. Colding, and C. Folke. 2002. Navigating socialecological systems: building resilience for complexity and change. Cambridge University Press, Cambridge, UK. http://dx.doi. org/10.1017/CBO9780511541957

Birge, H. E., C. R. Allen, R. K. Craig, A. S. Garmestani, J. A. Hamm, C. Babbitt, K. Nemec, and E. Schlager. 2014. Socialecological resilience and law in the Platte River basin. Idaho Law Review 51:229. [online] URL: https://www.uidaho.edu/-/media/ UIdaho-Responsive/Files/law/law-review/articles/volume-51/51-1birge-hannah-etal.pdf?la=en \&hash=775E71012FD6D8477FC604EAB0CE510A2C8EA7DB

Blackmore, C. 2007. What kinds of knowledge, knowing and learning are required for addressing resource dilemmas?: a theoretical overview. Environmental Science and Policy 10 (6):512-525. http://dx.doi.org/10.1016/j.envsci.2007.02.007

Blackmore, C., R. Ison, and J. Jiggins. 2007. Social learning: an alternative policy instrument for managing in the context of Europe's water. Environmental Science and Policy 10(6):493-498. http://dx.doi.org/10.1016/j.envsci.2007.04.003

Borowski, I., J.-P. Le Bourhis, C. Pahl-Wostl, and B. Barraqué. 2008. Spatial misfit in participatory river basin management: effects on social learning, a comparative analysis of German and
French case studies. Ecology and Society 13(1):7. http://dx.doi. org/10.5751/ES-02341-130107

Buck, L., E. Wollenberg, and D. Edmunds. 2001. Social learning in the collaborative management of community forests: lessons from the field. Pages 1-20 in E. Wollenberg, L. Buck, J. Fox, and S. Brodt, editors. Social learning in community forest. CIFOR, Bogor, Indonesia.

Chaffin, B. C., A. S. Garmestani, H. Gosnell, and R. K. Craig. 2016. Institutional networks and adaptive water governance in the Klamath River Basin, USA. Environmental Science and Policy 57(March):112-121. http://dx.doi.org/10.1016/j.envsci.2015.11.008

Country Administrative Boards (CAB). 2003. Omprövningar av vattendomar inom Ljusnans avrinningsområde. Del 1. Huvudrapport [Review of permits for water operations in Ljusnan River Basin. Part 1. Main report. A common project by Gävleborg and Jämtlands county administrative boards as well as Söderhamn, Ljusdal, Bollnäs, Ovanåker, and Härjedalen municipalities]. CAB, Gävleborg and Jämtland, Sweden.

Country Administrative Boards (CAB). 2007. Omprövning av villkoren för vattenkraftsanläggningar i övre Ljusnan [Review of permits for hydropower facilities in upper Ljusnan]. CAB, Jämtland, Sweden.

Country Administrative Boards (CAB). 2008. Annex 2 - Ljusnan. Fria Vandringsvägar, redovisning av regeringsuppdrag $51 a$ Modeller för arbetet med restaurering av vattendrag och omprövning av vattendomar [Annex 2 - Ljusnan. Open passage, account of government directive 51a - models of work with river restoration and permit reviews]. CAB, Gästernorrland and Östergöland, Sweden.

Crona, B. I., and J. N. Parker. 2012. Learning in support of governance: theories, methods, and a framework to assess how bridging organizations contribute to adaptive resource governance. Ecology and Society 17(1):32. http://dx.doi. org/10.5751/ES-04534-170132

Cundill, G., and R. Rodela. 2012. A review of assertions about the processes and outcomes of social learning in natural resource management. Journal of Environmental Management 113:7-14. http://dx.doi.org/10.1016/j.jenvman.2012.08.021

Dale, N. 1989. Getting to co-management: social learning in the redesign of fisheries management. Pages 49-72 in E. Pinkerton, editor. Co-operative management of local fisheries: new directions for improved management and community development. University of British Columbia Press, Vancouver, British Columbia, Canada.

Daniels, S. E., and G. B. Walker. 1996. Collaborative learning: improving public deliberation in ecosystem-based management. Environmental Impact Assessment Review 16(2):71-102. http://dx. doi.org/10.1016/0195-9255(96)00003-0

de Kraker, J. 2017. Social learning for resilience in socialecological systems. Current Opinion in Environmental Sustainability 28:100-107. http://dx.doi.org/10.1016/j.cosust.2017.09.002

Dyball, R., V. A. Brown, and M. Keen. 2007. Towards sustainability: five strands of social learning. Pages 181-194 in A. E. J. Wals, editor. Social learning towards a sustainable world: 
principles, perspectives, and praxis. Wageningen Academic, Wageningen, The Netherlands.

Électricité de France (EDF). 2015. EDF production hydroélectrique Vallée de La Dordogne. Nos actions en 2015 [EDF hydropower production in the Dordogne valley. Our activities in 2015]. EDF, Paris, France. [online] URL: https://www.edf.fr/sites/ default/files/Hydraulique/Dordogne/documents/plaquette geh dordogne. pdf

European Commission (EC). 2018. Eurostat: hydropower. European Commission, Brussels, Belgium. [online] URL: $\underline{\text { http:// }}$ ec.europa.eu/eurostat/web/environmental-data-centre-on-naturalresources/natural-resources/energy-resources/hydropower

Federal Energy Regulatory Commission (FERC). 2011. Ideas for implementing and participating in the integrated licensing process (ILP). Tools for industry, agencies, tribes, non-governmental organizations, citizens, and FERC staff. Version 2.0. Federal Energy Regulatory Commission, Washington, D.C., USA. [online] URL: https://www.ferc.gov/industries/hydropower/geninfo/licensing/ilp/eff-eva/ideas.pdf

Folke, C., T. Hahn, P. Olsson, and J. Norberg. 2005. Adaptive governance of social-ecological systems. Annual Review of Environment and Resources 30:441-473. http://dx.doi.org/10.1146/ annurev.energy.30.050504.144511

Fortum. 2017. Fortums vattenkraftverk runt om i Sverige och Finland [Fortum's hydropower stations in Sweden and Finland]. Fortum, Espoo, Finland. [online] URL: http://www.fortum.com/ countries/se/om-fortum/energi-produktion/vattenkraft/vattenkraftverk/ pages/default.aspx.

Gerlak, A. K., T. Heikkila, S. L. Smolinski, D. Huitema, and D. Armitage. 2018. Learning our way out of environmental policy problems: a review of the scholarship. Policy Sciences 51:335-371. http://dx.doi.org/10.1007/s11077-017-9278-0

Hisschemöller, M., and R. Hoppe. 1995. Coping with intractable controversies: the case for problem structuring in policy design and analysis. Pages 40-60 in M. Hisschemöller, R. Hoppe, W. N. Dunn, and J. R. Ravetz, editors. Knowledge, power and participation in environmental policy analysis. Routledge, London, UK. http://dx.doi.org/10.1007/BF02832229

Ison, R., N. Röling, and D. Watson. 2007. Challenges to science and society in the sustainable management and use of water: investigating the role of social learning. Environmental Science and Policy 10(6):499-511. http://dx.doi.org/10.1016/j.envsci.2007.02.008

Jordan, A., R. K. W. Wurzel, and A. Zito. 2005. The rise of 'new' policy instruments in comparative perspective: has governance eclipsed government? Political Studies 53(3):477-496. http://dx. doi.org/10.1111/j.1467-9248.2005.00540.x

Keen, M., V. A. Brown, and R. Dyball. 2005. Social learning in environmental management: towards a sustainable future. Routledge, London, UK.

Knill, C., and A. Lenschow. 2000. Implementing EU environmental policy: new directions and old problems. Manchester University Press, Manchester, UK.

Lee, K. N. 1993. Compass and gyroscope: integrating science and politics for the environment. Island, Washington, D.C., USA.
Mostert, E., C. Pahl-Wostl, Y. Rees, B. Searle, D. Tàbara, and J. Tippett. 2007. Social learning in European river-basin management: barriers and fostering mechanisms from 10 river basins. Ecology and Society 12(1):19. http://dx.doi.org/10.5751/ ES-01960-120119

Muro, M., and P. Jeffrey. 2008. A critical review of the theory and application of social learning in participatory natural resource management processes. Journal of Environmental Planning and Management 51(3):325-344. http://dx.doi.org/10.1080/09640560$\underline{801977190}$

Newig, J., and T. M. Koontz. 2014. Multi-level governance, policy implementation and participation: the EU's mandated participatory planning approach to implementing environmental policy. Journal of European Public Policy 21(2):248-267. http://dx. doi.org/10.1080/13501763.2013.834070

Olsson, P., C. Folke, and F. Berkes. 2004. Adaptive comanagement for building resilience in social-ecological systems. Environmental Management 34(1):75-90. http://dx.doi.org/10.1007/s00267-003-0101-7

Opperman, J. J., C. Apse, F. Ayer, J. Banks, L. R. Day, J. Royte, and J. Seebach. 2011a. Hydropower, salmon and the Penobscot River (Maine, USA): pursuing improved environmental and energy outcomes through participatory decision-making and basin-scale decision context. Pages 311-336 in J. Burger, editor. Stakeholders and scientists: achieving implementable solutions to energy and environmental issues. Springer, New York, New York, USA. http://dx.doi.org/10.1007/978-1-4419-8813-3_13

Opperman, J. J., J. Royte,, J. Banks, L. R. Day, and C. Apse. 2011 b. The Penobscot River, Maine, USA: a basin-scale approach to balancing power generation and ecosystem restoration. Ecology and Society 16(3):7. http://dx.doi.org/10.5751/ES-04117-160307

Pahl-Wostl, C., M. Craps, A. Dewulf, E. Mostert, D. Tabara, and T. Taillieu. 2007. Social learning and water resources management. Ecology and Society 12(2):5. http://dx.doi. org/10.5751/ES-02037-120205

Pahl-Wostl, C., E. Mostert, and D. Tàbara. 2008. The growing importance of social learning in water resources management and sustainability science. Ecology and Society 13(1):24. http://dx.doi. org/10.5751/ES-02352-130124

Pinkerton, E. W. 1994. Local fisheries co-management: a review of international experiences and their implications for salmon management in British Columbia. Canadian Journal of Fisheries and Aquatic Sciences 51(10):2363-2378. http://dx.doi.org/10.1139/ f94-238

Reed, M. S. 2008. Stakeholder participation for environmental management: a literature review. Biological Conservation 141 (10):2417-2431. http://dx.doi.org/10.1016/j.biocon.2008.07.014

Reed, M., A. C. Evely, G. Cundill, I. Fazey, J. Glass, A. Laing, J. Newig, B. Parrish, C. Prell, C. Raymond, and L. C. Stringer. 2010. What is social learning? Ecology and Society 15(4):r1. http://dx. doi.org/10.5751/ES-03564-1504r01

Rodela, R. 2013. The social learning discourse: trends, themes and interdisciplinary influences in current research. Environmental Science and Policy 25:157-166. http://dx.doi.org/10.1016/j. envsci.2012.09.002 
Röling, N. 2002. Beyond the aggregation of individual preferences: moving from multiple to distributed cognition in resource dilemmas. Pages 25-48 in C. Leeuwis and R. Pyburn, editors. Wheelbarrows full of frogs: social learning in rural resource management. Koninklijke Van Gorcum, Assen, The Netherlands.

Rudberg, P. M. 2013. Sweden's evolving hydropower sector: renovation, restoration and concession change. Stockholm Environment Institute, Stockholm, Sweden. [online] URL: https://www.sei.org/publications/swedens-evolving-hydropower-sectorrenovation-restoration-and-concession-change/

Rudberg, P. M., M. Escobar, J. Gantenbein, and N. Niiro. 2015. Mitigating the adverse effects of hydropower projects: a comparative review of river restoration and hydropower regulation in Sweden and the United States. Georgetown Environmental Law Review 27:251-274. [online] URL: https:// www.sei.org/publications/mitigating-the-adverse-effects-of-hydropowerprojects-a-comparative-review-of-river-restoration-and-hydropowerregulation-in-sweden-and-the-united-states/

Schusler, T. M., D. J. Decker, and M. J. Pfeffer. 2003. Social learning for collaborative natural resource management. Society and Natural Resources 16(4):309-326. http://dx.doi. org/10.1080/08941920390178874

Siebenhüner, B., R. Rodela, and F. Ecker. 2016. Social learning research in ecological economics: a survey. Environmental Science and Policy 55(Part 1):116-126. http://dx.doi.org/10.1016/j. envsci.2015.09.010

Steyaert, P., and J. Jiggins. 2007. Governance of complex environmental situations through social learning: a synthesis of SLIM's lessons for research, policy and practice. Environmental Science and Policy 10(6):575-586. http://dx.doi.org/10.1016/j. envsci.2007.01.011

Suškevičs, M., T. Hahn, R. Rodela, B. Macura, and C. Pahl-Wostl. 2018. Learning for social-ecological change: a qualitative review of outcomes across empirical literature in natural resource management. Journal of Environmental Planning and Management 61:1085-1112. http://dx.doi.org/10.1080/09640568.2017 .1339594

Svensk Författningssamling (SFS). 1998. Lag om införande av miljöbalken [Implementation of the Swedish environmental code act] 1998:881. Svensk Författningssamling, Stockholm, Sweden.

Swedish Energy Agency. 2014. Vad avgör ett vattenkraftverks betydelse för elsystemet. Underlag till nationell strategiför åtgärder inom vattenkraften [What determines a hydropower station's importance in the electric system. Information for the national strategy for measures concerning hydropower]. Swedish Energy Agency, Stockholm, Sweden. [online] URL: https://www. energimyndigheten.se/globalassets/nyheter/2014/vad-avgor-ettvattenkraftverks-betydelse-for-elsystemet.pdf

Van Bommel, S., N. Röling, N. Aarts, and E. Turnhout. 2009. Social learning for solving complex problems: a promising solution or wishful thinking? A case study of multi-actor negotiation for the integrated management and sustainable use of the Drentsche Aa area in the Netherlands. Environmental Policy and Governance 19(6):400-412. http://dx.doi.org/10.1002/eet.526 van den Hove, S. 2006. Between consensus and compromise: acknowledging the negotiation dimension in participatory approaches. Land Use Policy 23(1):10-17. http://dx.doi. org/10.1016/j.landusepol.2004.09.001

Vatn, A. 2005. Institutions and the environment. Edward Elgar, Cheltenham, UK.

Wals, A. E. J. 2007. Social learning towards a sustainable world: principles, perspectives, and praxis. Wageningen Academic, Wageningen, The Netherlands. http://dx.doi.org/10.3920/978-90-8686-594-9

Walters, C. 1986. Adaptive management of renewable resources. MacMillan, New York, New York, USA. 


\section{APPENDIX 1: BACKGROUND AND DEVELOPMENT OF THE RESEARCH FRAMEWORK}

\section{Identified factors in the three reviews}

Review 1: Muro, M., and P. Jeffrey. 2008. "A Critical Review of the Theory and Application of Social Learning in Participatory Natural Resource Management Processes.” Journal of Environmental Planning and Management 51 (3): 325 344.

This review identifies various "process features that foster social learning", as well as "conditions that limit opportunities for social learning processes" based on a review of an unspecified number of papers of social learning in participatory natural resource management processes. The identified features and conditions are presented in Appendix Table 1.

\section{Appendix Table 1: Process features and conditions identified in Muro and Jeffrey 2008}

\begin{tabular}{|l|l|}
\hline "Process features that foster social learning" & "Conditions that limit opportunities for social learning processes" \\
\hline Facilitation & Nature of problem at hand \\
\hline Small group work & Very rigid institutional framework \\
\hline Egalitarian atmosphere & \\
\hline Repeated meetings & \\
\hline Opportunities to influence the process & \\
\hline Open communication & \\
\hline Diverse participation & \\
\hline Unrestrained thinking & \\
\hline Multiple sources of knowledge & \\
\hline
\end{tabular}

Review 2: Cundill, G., and R. Rodela. 2012. "A Review of Assertions about the Processes and Outcomes of Social Learning in Natural Resource Management.” Journal of Environmental Management 113: 7-14.

This review identifies "emerging assertions about processes that support social learning" based on a review of definitions of social learning extracted from a sample of 54 articles. These emerging assertions are presented in Appendix Table 2.

Appendix Table 2: Emerging assertions identified in Cundill and Rodela 2012

\begin{tabular}{|l|}
\hline $\begin{array}{l}\text { "Emerging assertions about processes that support } \\
\text { social learning" }\end{array}$ \\
\hline Deliberate experimentation \\
\hline On-going monitoring \\
\hline Joint actions \\
\hline Reflective practice \\
\hline Knowledge sharing \\
\hline Deliberation \\
\hline Sustained interaction \\
\hline Exposure of values \\
\hline Trust building \\
\hline Long term-self organizing process \\
\hline Experience of crisis \\
\hline Iterative reflection \\
\hline
\end{tabular}

Review 3: Siebenhüner, B., R. Rodela, and F. Ecker. 2016. "Social Learning Research in Ecological Economics: A Survey." Environmental Science \& Policy 55 (Part 1): 116-26.

This review identifies "causal factors for the emergence of social learning processes" based on a review of 45 articles treating social learning studies. The identified causal factors are presented in Appendix Table 3.

\section{Appendix Table 3: Causal factors identified in Siebenhüner et al. 2016}

\begin{tabular}{|l|}
\hline $\begin{array}{l}\text { "Identified causal factors for the emergence of social } \\
\text { learning processes" }\end{array}$ \\
\hline Social capital and networks (identified in 35 articles) \\
\hline Institutional make-up (identified in 24 articles) \\
\hline Environmental crisis (identified in 12 articles) \\
\hline
\end{tabular}




\begin{tabular}{|l|}
\hline Monitoring and evaluation (identified in 7 articles) \\
\hline Incentives (identified in 7 articles) \\
\hline Internal drivers (identified in 5 articles) \\
\hline Technology (identified in 1 article) \\
\hline
\end{tabular}

\section{Recapitulation of identified factors in the three reviews}

Based on the identified factors in the reviews we contend that most factors can meaningfully be grouped into the two overarching groups of "procedural" and "institutional" factors. Using terms and examples from the reviews and the reviewed literature, the identified factors in the three reviews are recapitulated as a total of 9 factors that are included in the framework of the paper (Table 1). Appendix Tables 4 and 5 illustrate how different identified procedural and institutional factors from the three reviews have been groped together and recapitulated for inclusion in the framework of the paper.

\section{Appendix Table 4: Recapitulation of procedural factors}

\begin{tabular}{|c|c|c|c|c|}
\hline Review & \multicolumn{4}{|c|}{ Identified procedural factors } \\
\hline $\begin{array}{l}\text { Muro and Jeffrey } \\
2008\end{array}$ & - Repeated meetings & $\begin{array}{l}\text { - Opportunities to } \\
\text { influence the process } \\
\text { - Multiple sources of } \\
\text { knowledge }\end{array}$ & $\begin{array}{l}\text { - Facilitation } \\
\text { - Small group work } \\
\text { - Open communication } \\
\text { - Unrestrained } \\
\text { thinking }\end{array}$ & $\begin{array}{l}\text { - Diverse } \\
\text { participation }\end{array}$ \\
\hline $\begin{array}{l}\text { Cundill and Rodela } \\
2012\end{array}$ & $\begin{array}{l}\text { - Sustained interaction } \\
\text { - Iterative reflection }\end{array}$ & $\begin{array}{l}\text { - Deliberate } \\
\text { experimentation } \\
\text { - On-going monitoring } \\
\text { - Joint actions } \\
\text { - Knowledge sharing } \\
\text { - Reflective practice } \\
\text { - Deliberation } \\
\end{array}$ & - Exposure of values & \\
\hline $\begin{array}{l}\text { Sibenhüner et al. } \\
2016\end{array}$ & & $\begin{array}{l}\text { - Monitoring and } \\
\text { evaluation } \\
\text { - Technology }\end{array}$ & & \\
\hline Recapitulated as & Sustained interaction & $\begin{array}{l}\text { Joint knowledge } \\
\text { acquisition, sharing and } \\
\text { deliberation }\end{array}$ & Skilled facilitation & $\begin{array}{l}\text { Inclusion of } \\
\text { relevant } \\
\text { stakeholders }\end{array}$ \\
\hline
\end{tabular}

\section{Appendix Table 5: Recapitulation of institutional factors}

\begin{tabular}{|l|l|l|l|l|l|}
\hline Review & \multicolumn{4}{|c|}{ Identified institutional factors } \\
\hline $\begin{array}{l}\text { Muro and Jeffrey } \\
2008\end{array}$ & $\begin{array}{l}\text { - Egalitarian } \\
\text { atmosphere }\end{array}$ & & & $\begin{array}{l}\text { - Very rigid } \\
\text { institutional } \\
\text { framework* }\end{array}$ & $\begin{array}{l}\text { - Very rigid } \\
\text { institutional } \\
\text { framework* }\end{array}$ \\
\hline $\begin{array}{l}\text { Cundill and Rodela } \\
2012\end{array}$ & - Trust building & & & \\
\hline $\begin{array}{l}\text { Sibenhüner et al. } \\
2016\end{array}$ & $\begin{array}{l}\text { - Social capital } \\
\text { and networks }\end{array}$ & $\begin{array}{l}\text { - Institutional } \\
\text { make-up* }\end{array}$ & $\begin{array}{l}\text { - Institutional } \\
\text { make-up* }\end{array}$ & $\begin{array}{l}\text { - Institutional } \\
\text { make-up* }\end{array}$ & $\begin{array}{l}\text { - Institutional } \\
\text { make-up* }\end{array}$ \\
\hline Recapitulated as & $\begin{array}{l}\text { Social capital } \\
\text { and networks }\end{array}$ & $\begin{array}{l}\text { Capability of } \\
\text { formalizing new } \\
\text { practices, } \\
\text { arrangements, } \\
\text { norms and } \\
\text { values }\end{array}$ & $\begin{array}{l}\text { An organization } \\
\text { that fits the } \\
\text { relevant } \\
\text { ecological unit }\end{array}$ & $\begin{array}{l}\text { Authorities } \\
\text { lacking } \\
\text { experience, } \\
\text { facing special } \\
\text { misfits and } \\
\text { problems of } \\
\text { coordination }\end{array}$ & $\begin{array}{l}\text { Stakeholders } \\
\text { possessing } \\
\text { strong pre- } \\
\text { existing rights } \\
\text { over the natural } \\
\text { resource }\end{array}$ \\
\hline
\end{tabular}

*Section 2 of the paper explains that the reviews provide examples of these factors that fit into the grouping and recapitulation made in the paper.

\section{Reasons behind excluding a limited number of factors identified in the three reviews}

There are a limited number of factors identified in the three reviews that do not fit the framework of the paper. These are "Nature of problem at hand"; "Long term self-organizing process"; "Experience of crisis"; "Environmental crisis"; "Incentives" and "Internal drivers".

The reasons for this are that the identified factor is either too vague to use - "Nature of problem at hand" - or is not relevant to the focus of this article on learning-based interventions: "Long term self-organizing process". The factors "Incentives", "internal drivers", "experience of crisis" and "environmental crisis" were not included in the framework since the factors do not fit well into either of the two overall groups procedural and institutional factors. The value of creating a simple and 
parsimonious framework, with only two overall groupings that together cover the most significant identified factors, was deemed higher than the value of adding additional groups of factors to the framework to be able to include these four factors. 